\title{
Geophysical approach to delineate arsenic hot spots in the alluvial aquifers of Bhagalpur district, Bihar (India) in the central Gangetic plains
}

\author{
Pankaj Kumar • Ram Avtar • Alok Kumar • \\ Chander Kumar Singh • Parijat Tripathi • \\ G. Senthil Kumar • A. L. Ramanathan
}

Received: 16 April 2013/ Accepted: 9 October 2013/Published online: 24 October 2013

(C) The Author(s) 2013. This article is published with open access at Springerlink.com

\begin{abstract}
A combined study of the geophysical survey and hydro-geochemistry in the Quaternary alluvial aquifers of Bhagalpur district from Bihar state in central Gangetic plain of India was carried out with the objective of identifying the geochemical processes and their relation with lithological profile. Results of resistivity survey validated with borehole lithology gave us a clear picture of the geological signature of the aquifers, which support the reducing nature of the aquifer where concentration of arsenic was high. Reducing nature of the aquifer environment was shown by water samples having relatively negative Eh value. From XRD study of the soil samples, it was found that goethite, dolomite, calcite, quartz and feldspar are the major minerals for most of the samples. Output of this work concludes that resistivity survey is an economically feasible tool which can be successfully used to target arsenic-safe aquifers on wide scale.
\end{abstract}

Keywords Resistivity survey · Hydro-geochemistry · Alluvial aquifers · Gangetic plains · Arsenic

\footnotetext{
P. Kumar

Institute of Science and Technology for Advance Studies and Research (ISTAR), Vallabh Vidyanagar, Gujarat 388120, India

R. Avtar

Institute of Industrial Science, The University of Tokyo, Ce 509,

4-6-1, Komaba, Meguro-Ku, Tokyo 153-8505, Japan

P. Kumar $(\bowtie) \cdot$ A. Kumar · C. K. Singh · P. Tripathi ·

G. Senthil Kumar · A. L. Ramanathan

School of Environmental Sciences, Jawaharlal Nehru University, New Delhi, India

e-mail: pankajenvsci@gmail.com
}

\section{Introduction}

The occurrence of arsenic (As)-rich alluvial groundwater is a worldwide problem (Kumar et al. 2010). Most studies of As pollution have focused on the predominance of As poisoning in the groundwater of West Bengal (India) and Bangladesh and thought to be limited to the Ganges Delta, i.e., the lower Gangetic plain (Bhattacharya et al. 1997; Ahmed et al. 2004; Ben et al. 2003). Some states such as Uttar Pradesh and Bihar reported the presence of elevated concentrations of arsenic in drinking water wells sporadically (Acharyya and Shah 2004; Chakraborti et al. 2004; Acharyya 2005; Chauhan et al. 2009; Sankararamakrishnan et al. 2008; Srivastava et al. 2008; Kumar et al. 2010). Several authors suggested that the reductive dissolution of $\mathrm{Fe}(\mathrm{III})$-oxyhydroxides in strongly reducing conditions in the young alluvial Holocene sediments is the cause for arsenic mobilization (Harvey et al. 2002; Nickson et al. 1998, 2000). Groundwater quality is controlled by various factors viz. composition of recharging water, the mineralogy and reactivity of the geological formations in the region of aquifer recharges, the impact of human activities and the environmental parameters that may control the geochemical mobility of redox (oxidation and reduction potential varies from 169 to $-134 \mathrm{mv}$, respectively, in this case) sensitive elements in the groundwater environment (Bhattacharya et al. 2009). The arsenic-contaminated aquifers are persistent within lowland organic rich, clayey deltaic sediments in the Bengal Basin and locally within similar facies in narrow, entrenched river valleys within the Gangetic alluvial plain (Acharyya and Shah 2004; Acharyya 2005).

The current drinking water quality guideline for arsenic is $0.01 \mathrm{mg} / \mathrm{L}$ (WHO 2004). Contaminated drinking water (i.e., water samples having arsenic in excess of 
abovementioned permissible limit/concentration level) is the main source of chronic human intoxication (Gabel 2000; Smith et al. 2000), which results in skin ailments such as hyperpigmentation and keratosis, and leads progressively to cancer and ultimately death (WHO 2004; National Academy Press 2001). In south Asia, enrichment of arsenic (As) in groundwater possesses a serious health threat not only limited to human being (e.g., circulatory disease, neurological effects, black foot disease and carcinogenicity) but also accumulates in plants and fish (Nath et al. 2010).

Electrical resistivity is primarily a function of porosity, pore fluid resistivity (salinity), mineral content, texture, moisture content, fissures and fractures of geological formations, temperature and clay content. The resistivity value of rocks varies depending upon the presence of secondary porosity such as weathered, fractured and joints (Yadav and Singh 2007; Raju and Reddy 1998). The resistivity value depends more on water content and quality in a porous aquifer as compared to hard rock aquifer. For aquifers composed of unconsolidated materials, the resistivity decreases with the degree of saturation and the salinity of groundwater. Clay minerals conduct current through their matrix, therefore, clay formations tend to display lower resistivity then do permeable alluvial aquifers (Mukherjee et al. 2007). Resistivity methods are intensively used by geophysicists for evaluation of subsurface features (Rhoades et al. 1990). Several methods such as Schlumberger, Wenner, pole-dipole and dipole-dipole have been used in several studies for delineating subsurface features. The probes are applied on the soil surface as well as in borehole logging (Rhoades and Schilfgaarde 1976). Vertical electrical sounding was applied to estimate hydraulic conductivity (Mazac et al. 1990) and texture (Banton et al. 1997) of the stratified soils and sediments.

Though there are few studies on resistivity application to locate arsenic "hotspots" through lithological characterization in lower Gangetic plain (Charlet et al. 2007; Aziz et al. 2008; Hoque et al. 2009; Nath et al. 2010), the idea is fairly new in case of middle Gangetic plain. Because of patchy distribution of As, drilling and geochemical study at point scale can only help to target As-safe aquifers, however, these are economically not viable in developing countries like India, Bangladesh. Therefore, this study strives to show the hydro-geochemical signature along with spatial distribution of $\mathrm{As}$ and $\mathrm{Fe}$ in Bhagalpur district in middle Gangetic plain. We used the above findings as a validation tool while targeting the As-safe aquifer through geophysical survey which is cost effective. It will definitely help in sustainable use of the As low aquifer which can reduce the future casualty due to its contamination.

\section{Study area}

Bhagalpur district is located in the eastern part of Bihar from $25^{\circ} 1329^{\prime}$ to $25^{\circ} 608^{\prime} \mathrm{N}$ latitude and from $86^{\circ} 6408^{\prime}$ to $87^{\circ} 542^{\prime} \mathrm{E}$ (Fig. 1). The district is a peneplain, intersected by numerous streams. Surface levels varied due to high banks of the Ganga, Koshi (Ghugri), Chanari, and Chandan. The geomorphology of the area is monotonously flat
Fig. 1 General geomorphology of Bhagalpur district, Bihar (India) (Kumar et al. 2010). (Resistivity surveys were conducted along the points shown in brown color)

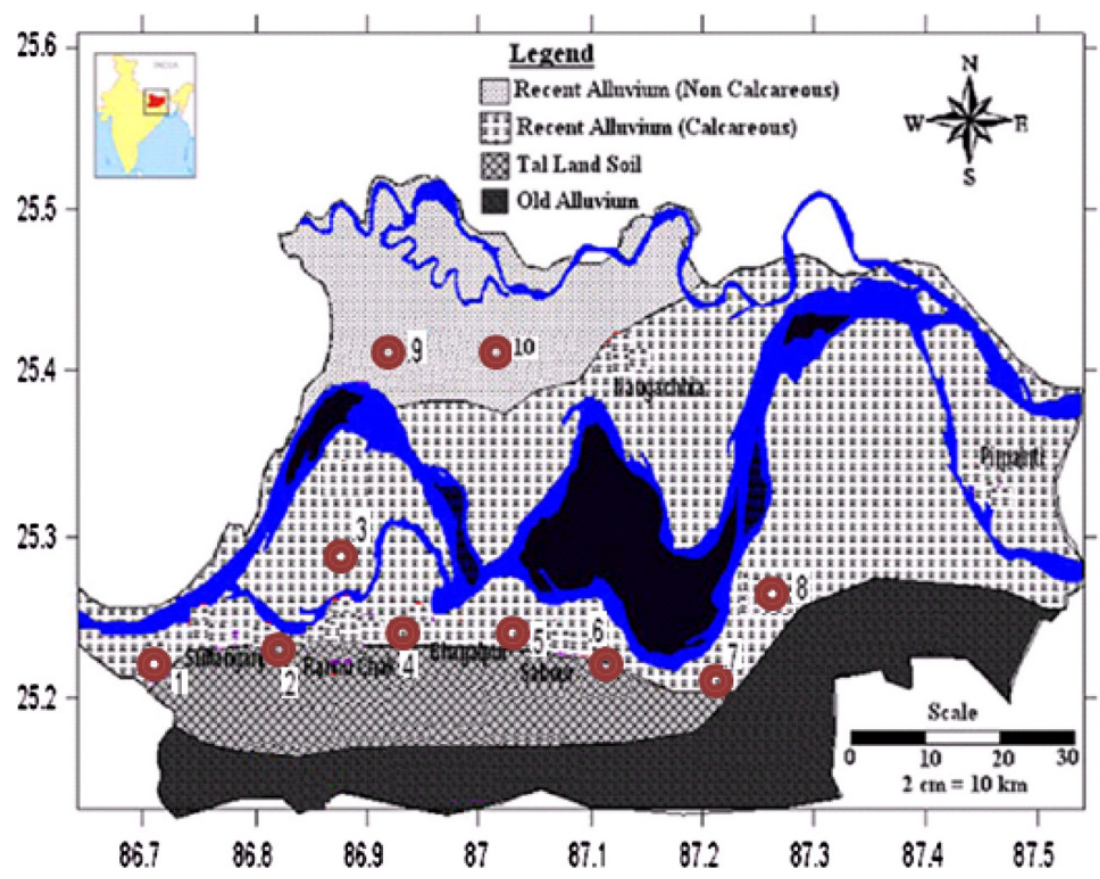


and featureless plain with gradient towards the river Ganges.

\section{Geology and hydrogeology}

Geologically, the area is represented by alluvial deposits of Quaternary age. The area has been divided into four different zones: Recent alluvium (non calcareous), Recent alluvium (calcareous), Tal land soils and Older alluvium. The large-scale features of the Gangetic plain correspond to major climate changes in the late Quaternary (Singh 2004). The geomorphic surfaces identified in the regional mapping of the Quaternary deposits of the Gangetic plain are upland interfluvial surface $\left(\mathrm{T}_{2}\right)$, marginal fan upland surface (MP), mega fan surface (MF), piedmont fan surface (PF), river valley terrace surface $\left(\mathrm{T}_{1}\right)$ and active flood plain surface $\left(\mathrm{T}_{0}\right)$ (Singh 2004; Shah 2008) as shown in Fig. 2. A significant aspect of these surfaces is that all of them are depositional surfaces, having a succession of overlying sediments. The Bihar Gangetic plain shows prominent distinction between $\mathrm{T}_{0}, \mathrm{~T}_{1}$ and $\mathrm{T}_{2}$ surfaces. The Holocene aggradations, mostly due to rising base level and climate-driven sediment supply, are pronounced as much as 5-10 m thick. XRD studies on soil samples of arsenic-safe older alluvial and arsenic-contaminated newer alluvium from middle Gangetic plain reveal mineralogical assemblage of quartz, muscovite, chlorite, kaolinite feldspar, amphibole and goethite (Shah 2008). The depth of well in uppermost aquifer varies from 6 to $13 \mathrm{~m} \mathrm{bgl}$ (below ground level). The multiple aquifer system of this region has variable hydraulic conductivity and water quality. This district has two types of irrigation system: (a) canals and (b) tube wells.

\section{Materials and methods}

Sampling phase I

\section{Groundwater and core sampling and analysis}

Thirty-six groundwater samples (both from hand pumps/ tube wells) were collected in polypropylene bottles (Tarsons). Before sampling, groundwater was purged out from the wells for $5-10 \mathrm{~min}$ so that sufficient inflow is induced from the subsurface geological formation to the well and to minimize the impact of iron pipes through which water was pumped out. Further, these samples were stored below $4{ }^{\circ} \mathrm{C}$ in a portable ice-box to minimize chemical alteration. In-situ measurements mainly electrical conductivity (EC), $\mathrm{pH}$, and oxidation-reduction potential (ORP) were measured using a portable Orion Thermo water analyzing kit (Model Beverly, MA, USA; 01915) with a precision level of $1 \%$. Total arsenic was determined with the help of a Digital Arsenator (Wagtech, UK) and arsenic speciation was performed in the field with disposable cartridges (Metal Soft Center, PA, USA) with precision level of $5 \%$. Here, mode of operation is simple as it absorbs As (V), but allows As (III) to pass through and thus helps to identify different species of arsenic. The collected groundwater samples were filtered through $0.45 \mu \mathrm{m}$ Millipore filter paper. $\mathrm{H}_{3} \mathrm{BO}_{3}$ was used as preservative for nitrate analysis. $\mathrm{Fe}$ and $\mathrm{Mn}$ were analyzed in the laboratory using an atomic absorption spectrophotometer (AAS) (Shimadzu AA6800) with a precision level of $1 \%$. Concentrations of total arsenic were cross-checked on acidified samples using graphite furnace (GF) AAS (Shimadzu AA-6800) in absorption mode using chemical standards, with the
Fig. 2 Schematic model shows major As-contaminated zone in Newer alluvium ( $T_{0}$ surface) entrenched channels and floodplains and As-free zone in Older alluvium upland terraces $\left(\mathrm{T}_{2}\right.$ surface) in middle Ganga plain (Bihar, UP). Newer Alluvium older floodplains ( $\mathrm{T}_{1}$ surface) are locally Ascontaminated (Singh 2004; Shah 2008)
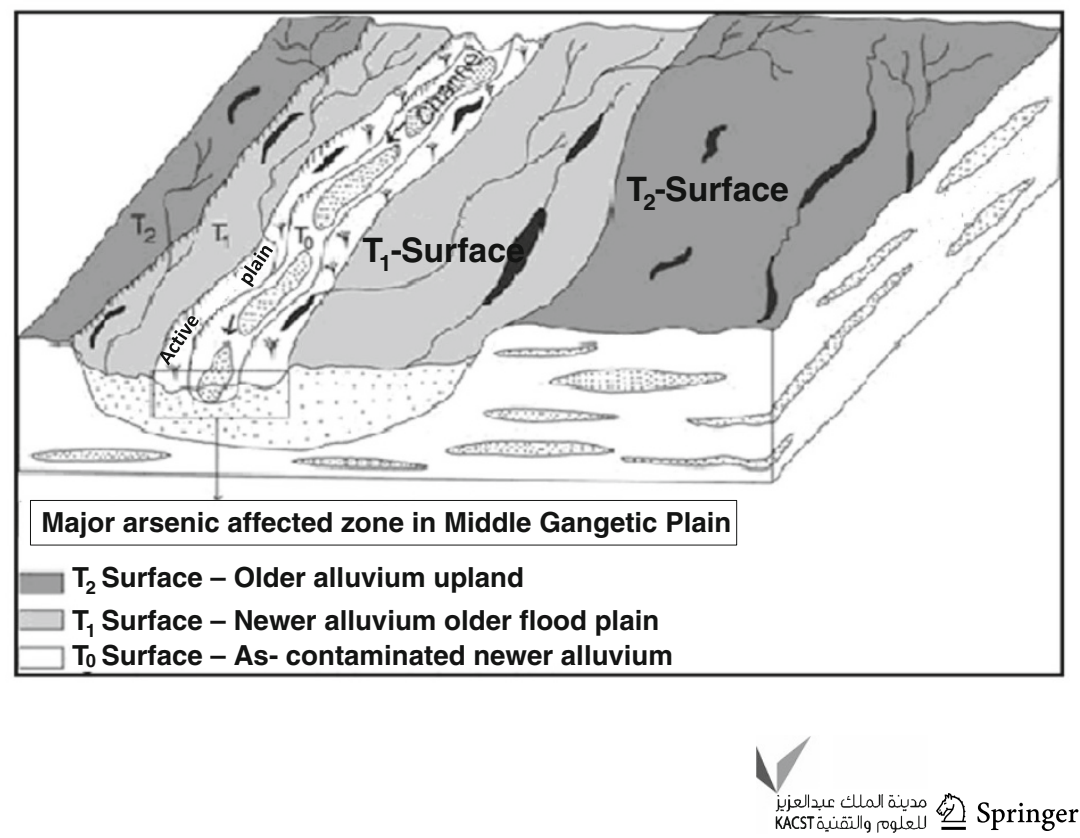
detection limit of $2 \mu \mathrm{g} / \mathrm{L}$. Major cations analysis was carried out by use of an EEL flame photometer with an error percentage of $<2 \%$ using duplicates (APHA 1995). The concentration of $\mathrm{HCO}_{3}{ }^{-}$was measured by acid titration. Other anions $\mathrm{F}^{-}, \mathrm{Cl}^{-}, \mathrm{NO}_{3}{ }^{-}, \mathrm{SO}_{4}{ }^{2-}$, and $\mathrm{PO}_{4}{ }^{3-}$ were analyzed by use of Dionex DX-120 ion chromatograph with a precision level of $1 \%$. Other characteristics, for example $\mathrm{SiO}_{2}$ and $\mathrm{NH}_{4}{ }^{+}$were analyzed with a Jenway model 6505 dual beam spectrophotometer. Highpurity reagents (Merck) and Milli-Q water (Model Milli$\mathrm{Q}$, Biocel) were used for all the analysis. The analytical precision for ions measurement was determined by calculating the ionic balance error which was in between $\pm 5 \%$ (Kumar et al. 2011).

One core sediment (up to $21 \mathrm{~m}$ depth from surface) was taken through borehole drilled with the help of local drillers using hand percussion technique (Kumar et al. 2010). Mineralogical study for clay at different lithological units is done with the help of XRD (PANalytical) to confirm arsenic enrichment.

\section{Sampling phase II}

\section{Geophysical survey}

To get insight of deep lithology, electrical resistivity surveys were carried out to determine the lithology, weathered, fractured pattern, depth to basement and resistivity variations in the study area. Ten vertical electrical soundings (VES) were taken at different locations within the study area. The Schlumberger method was used, in which the distance between the two current electrodes $(\mathrm{AB})$ is successively expanded, while the distance between the two potential electrodes (MN) is kept at a minimum $(\mathrm{MN} \leq 1 / 5 \mathrm{AB})$. Resistance was calculated, with the known value of position of current and potential electrodes.

The apparent resistivity is given by

$R_{\mathrm{a}}=\pi\left[\frac{S^{2}}{A}-\frac{A}{4}\right] \frac{V}{I}$

where, $S$ and $A$ are current and potential electrode spacing, $V$ is voltage difference between the potential electrodes, and $I$ is apparent current.

Increase in the distance between the electrodes leads to the greater depth penetration and gives information about more subsurface properties. The measured apparent resistivity values were plotted against the half the distance between current electrodes $(\mathrm{AB} / 2)$ on a $\log -\log$ graph to calculate the vertical electrical sounding curves, which were interpreted using IPI2 win software to determine the apparent resistivity and the thickness of subsurface layer of different composition.

\section{Results and discussion}

The value of resistivity has a direct relationship between porosity of subsurface material. Subsurface material with high porosity like sandstone generally leads to increase in resistivity value. So the variation in subsurface lithology of the aquifer can be clearly defined on the basis of vertical electrical sounding (VES). The statistical distribution of apparent resistivity for the study area is shown in Fig. 3, whereas depth wise resistivity profile for different locations of the study area is shown in Fig. 4.

As most of the study area region lies in Gangetic alluvial plain and the top horizon of soil has relatively high humus content with high cations exchange capacity; therefore, it provides high density of mobile electric charges and thus the resistivity value of this region is very low (Wilding et al. 1983). Points 1 and 2 show lower value of resistivity in the top most layers, but it increases with the depth. Here it is suggested that surface layer soil has higher salinity because of secondary salts such as chlorides and sulfates coming from organic matter breakdown and agricultural runoff carrying unutilized sulfates; ultimately results in lower value of resistivity. On the other hand, subsurface lithology is dominated with sand and silt with high porosity resulting into high resistivity. For points 3 and 4, since both of them located at meandering of river, i.e., active flood plain, they show low value of resistivity because of the presence of clay mineral in shallow subsurface layer (which is ranging from 6 to $15 \mathrm{~m}$ below ground level in this case). To validate this result, borehole lithology (taken near point 3 ) is presented along with the resistivity curve (Fig. 5), it was found that VES curve is consistent with the subsurface structure.

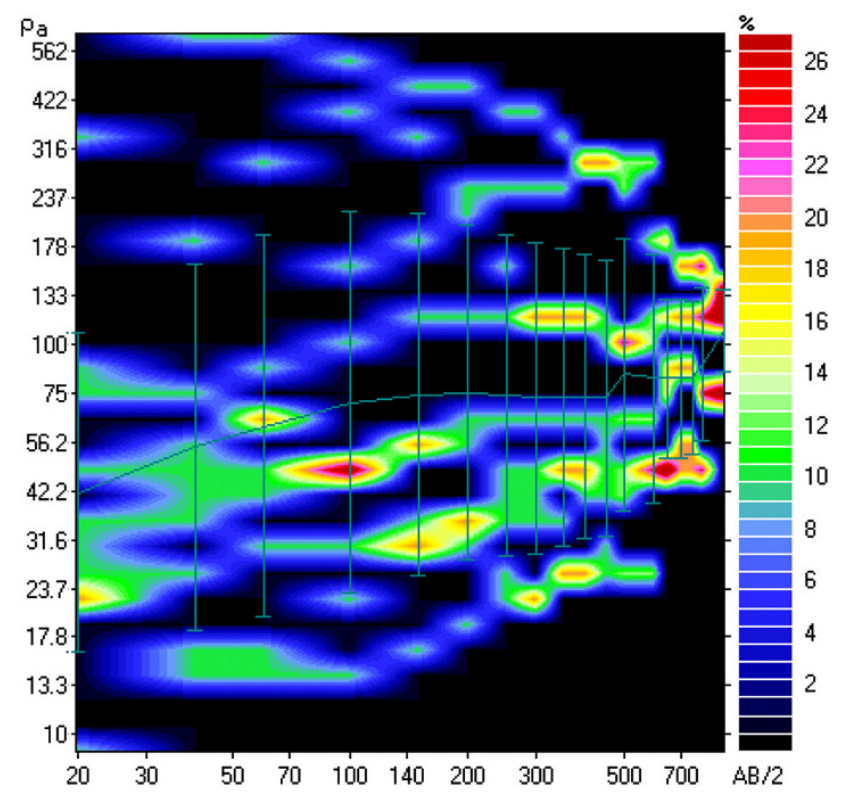

Fig. 3 Statistic distribution of apparent resistivity 


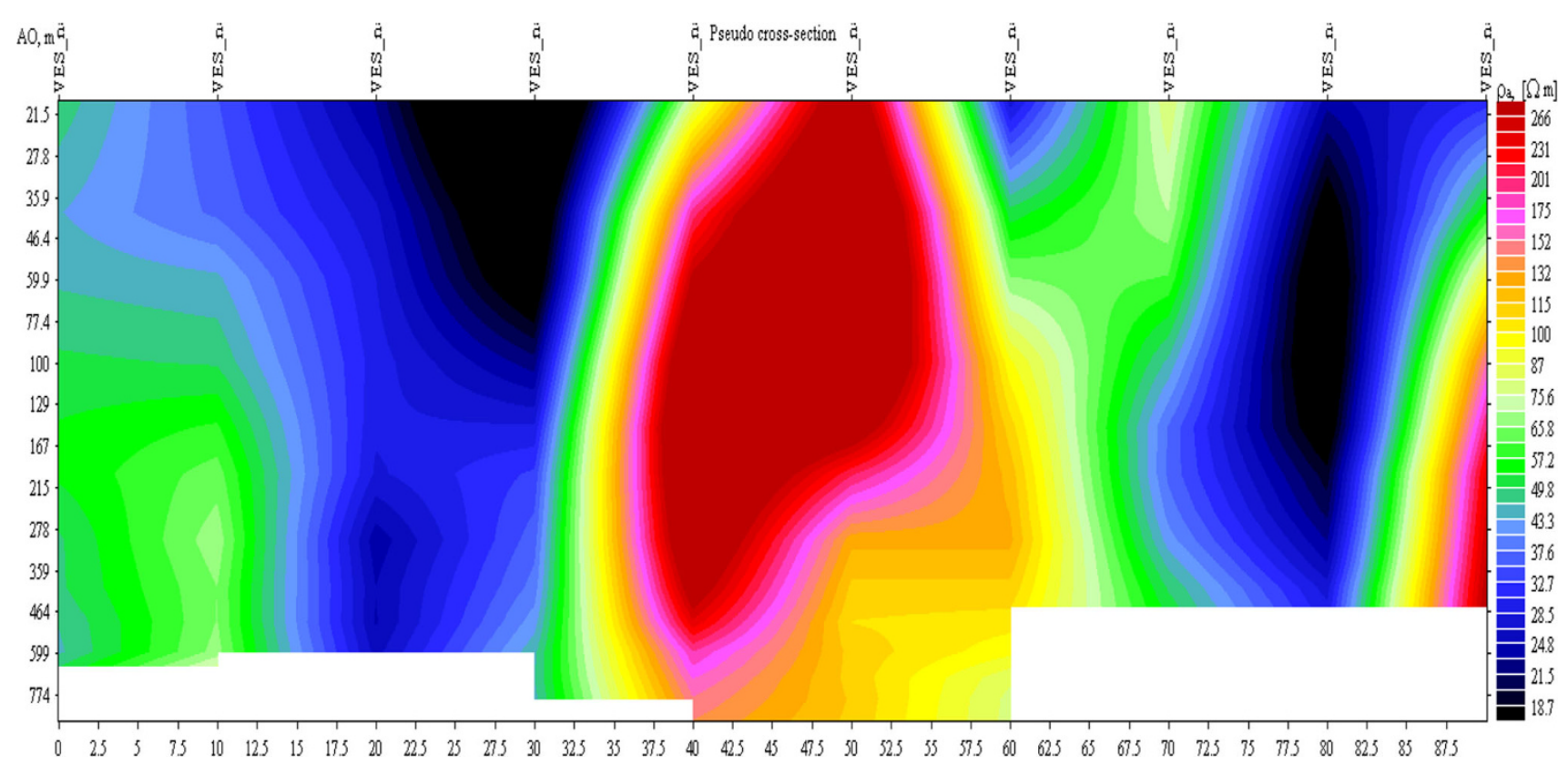

Fig. 4 Profile showing resistivity change with the depth in different location of the sounding of the study area (where horizontal and lateral distances are given in meters)
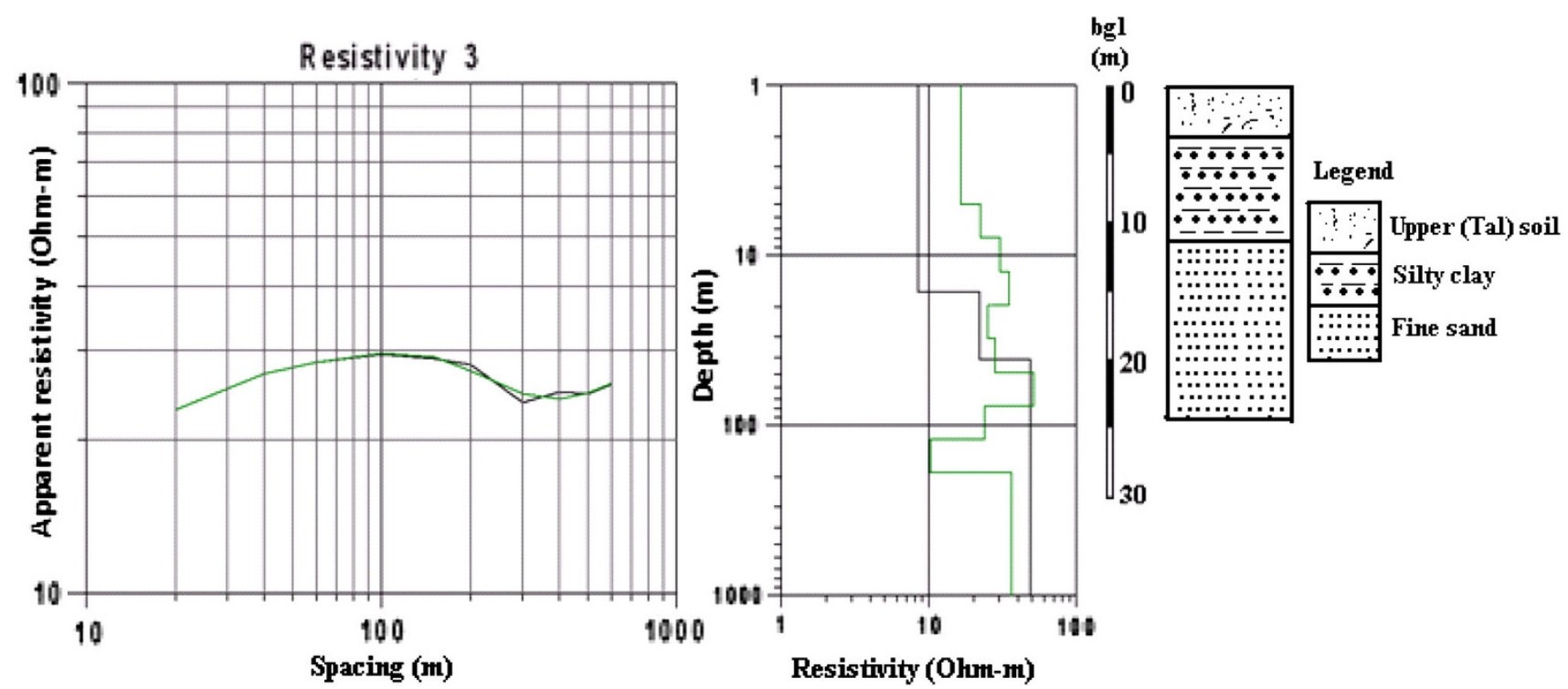

Fig. 5 Comparison between apparent and interpretive resistivity with the lithology of the borehole near to the point VES 3. Thick black lines denoting true/calculated resistivity value

Resistivity value was very low ( $>10 \Omega \mathrm{m}$ ) up to a depth of $16 \mathrm{~m}$ approximately due to presence of humus dominated top surface layer followed by thick layer of clay. From $16 \mathrm{~m}$ downward there is a huge deposition of homogenous fine sand layer which can be shown by increasing trend of resistivity value (Paranis 1997) with an exception of sudden decrease in resistivity value which might be because of thin layer of old alluvium which forms perched aquifer for few meters. Points 5 and 6 show sudden lateral increase in the value of resistivity is mainly because of presence of potential aquifer and presence of sandstone. However, for point 6 , through the examination for depth profile of resistivity, it was found that, value of resistivity decreases after a certain depth showing presence of clay layer. Lithological evidence indicates the presence of pyrites and dolomites in the sandstones which can contribute arsenic to groundwater.

For point 9 , because of bare soil with very high rate of evaporation upper horizon of soil has high salinity, which 
was well supported by relatively lower value of resistivity. The $\mathrm{pH}$ of the ground water varied in the range at $8.1 \pm 0.1$ (Table 1). It indicates that when iron is more the arsenic is retained on the iron compound and during favorable redox conditions ferric arsenate gets aerated and releases arsenic in water.

Table 1 Statistical analysis for water samples of Bhagalpur

\begin{tabular}{|c|c|c|c|c|c|c|}
\hline Parameters & Unit & Minimum & Maximum & Average & SD & $\begin{array}{l}\text { P.L. (WHO } \\
\text { 2004) }\end{array}$ \\
\hline Depth & (ft) & 30.0 & 95.0 & 55.7 & 34.6 & NA \\
\hline $\mathrm{Ph}$ & & 7.8 & 8.3 & 8.1 & 0.1 & 9.2 \\
\hline ORP & $\mathrm{mv}$ & -134.0 & 169.0 & 8.9 & 95.2 & NA \\
\hline $\mathrm{EC}$ & $\mu \mathrm{s} / \mathrm{cm}$ & 250.0 & 980.0 & 599.2 & 175 & 1,400 \\
\hline TDS & $\mathrm{mg} / \mathrm{L}$ & 191.2 & 710.0 & 455.2 & 133 & NA \\
\hline $\mathrm{Na}^{+}$ & $\mathrm{mg} / \mathrm{L}$ & 5.7 & 41.9 & 18.7 & 8.54 & 200 \\
\hline $\mathrm{K}^{+}$ & $\mathrm{mg} / \mathrm{L}$ & 0.4 & 3.2 & 1.4 & 0.7 & 150 \\
\hline $\mathrm{Ca}^{+2}$ & $\mathrm{mg} / \mathrm{L}$ & 20.7 & 126.0 & 64.8 & 30.3 & 200 \\
\hline $\mathrm{Mg}^{+2}$ & $\mathrm{mg} / \mathrm{L}$ & 7.8 & 18.2 & 10.7 & 2.2 & 150 \\
\hline $\mathrm{HCO}_{3}{ }^{-}$ & $\mathrm{mg} / \mathrm{L}$ & 15.2 & 214.5 & 104.8 & 42.2 & NA \\
\hline $\mathrm{F}^{-}$ & $\mathrm{mg} / \mathrm{L}$ & 0.1 & 4.9 & 0.8 & 0.9 & 1.5 \\
\hline $\mathrm{Cl}^{-}$ & $\mathrm{mg} / \mathrm{L}$ & 6.6 & 219.9 & 69.7 & 50.8 & 600 \\
\hline $\mathrm{NO}_{3}^{-}$ & $\mathrm{mg} / \mathrm{L}$ & 1.0 & 39.0 & 23.7 & 11.6 & 45 \\
\hline $\mathrm{SO}_{4}^{2-}$ & $\mathrm{mg} / \mathrm{L}$ & 3.8 & 72.8 & 32.9 & 20.2 & 400 \\
\hline $\mathrm{PO}_{4}^{3-}$ & $\mathrm{mg} / \mathrm{L}$ & 2.7 & 6.4 & 4.0 & 0.9 & 150 \\
\hline $\mathrm{SiO} 2$ & $\mathrm{mg} / \mathrm{L}$ & 14.0 & 49.3 & 30.0 & 8.1 & NA \\
\hline $\mathrm{NH}_{4}^{+}$ & $\mathrm{mg} / \mathrm{L}$ & 0.6 & 3.1 & 1.4 & 0.8 & NA \\
\hline $\mathrm{Fe}$ & $\mathrm{mg} / \mathrm{L}$ & 0.7 & 7.6 & 3.2 & 2.2 & 0.3 \\
\hline $\mathrm{Mn}$ & $\mathrm{mg} / \mathrm{L}$ & 0.01 & 1.8 & 0.7 & 0.6 & 0.1 \\
\hline As (tot) & $\mu \mathrm{g} / \mathrm{L}$ & 19.1 & 118.0 & 51.2 & 27.6 & 10 \\
\hline $\mathrm{As}^{3+}$ & $\mu \mathrm{g} / \mathrm{L}$ & 10.9 & 81.1 & 34.4 & 21.0 & 10 \\
\hline $\mathrm{As}^{5+}$ & $\mu \mathrm{g} / \mathrm{L}$ & 7.1 & 55.2 & 16.8 & 10.3 & 10 \\
\hline
\end{tabular}

P.L. permissible limit, $N A$ not applicable
Arsenic and its speciation

The statistics of general water geochemistry is given in Table 1. Total arsenic concentrations in the groundwater varied from 19.1 to $118 \mu \mathrm{g} / \mathrm{L}$ with an average value of $51.23 \mu \mathrm{g} / \mathrm{L}$ (Table 1). Distribution pattern of arsenic and iron in this area is shown in (Figs. 6, 7 respectively), from which it is observed that higher concentration of both the element is clustered near river Ganges and its tributary Koshi (Ghugri). From XRD study of the soil samples, it was found that goethite, dolomite, calcite, quartz and feldspar are the major minerals for most of the samples. Speciation modeling (calculated with the help of PHREEQC code) result for selected minerals in specified water samples is shown in Table 2. The result shows that the value for $\log \mathrm{PCO}_{2}$ is low for most of samples, i.e., all selected samples are under saturated with respect to it. Most samples are saturated with respect to calcite and dolomite, except for some samples from Golgamma, Panchrukhi, Marwa and Mahesitilakpur. Groundwater is undersaturated with respect to poorly crystalline minerals like $\mathrm{FeCO}_{3}$ and $\mathrm{Fe}(\mathrm{OH})_{3}$, but saturated with respect to goethite mineral. Hence, goethite is suggested as the sink for dissolved iron minerals which precipitates during oxidation may result in the de-coupling of $\mathrm{As}$ and $\mathrm{Fe}$ (Mukherjee et al. 2008). Here redox coupling (As (III)/As (V)) of As associated with $\mathrm{Fe}$ is assumed to govern arsenic mobilization in ground water. Oxyhydroxide reduction mechanism driven by microbial activity degrades the arsenate to arsenite and triggers the mobilization.

So presence of iron mineral associated with clay results in high conductance and thus low resistivity reaffirming the conclusion made for relatively lower resistivity value in case of clay layer at shallow depth for points 3 and 4. Most of the arsenic compounds are present in the form of sulfides
Fig. 6 Contour diagram showing spatial distribution of arsenic concentration $(\mu \mathrm{g} / \mathrm{L})$ (Kumar et al. 2010)

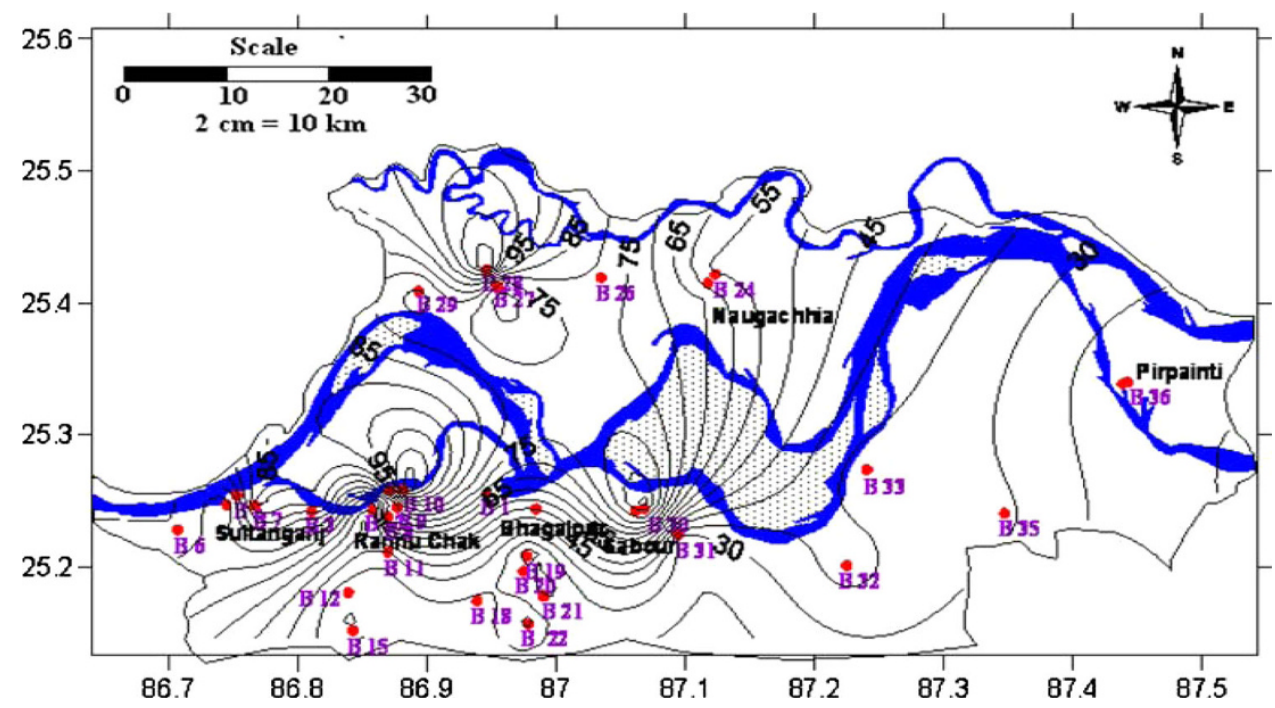


Fig. 7 Contour diagram showing spatial distribution of iron concentration $(\mathrm{mg} / \mathrm{L})$
Table 2 Speciation modeling result for selected minerals in specified water samples

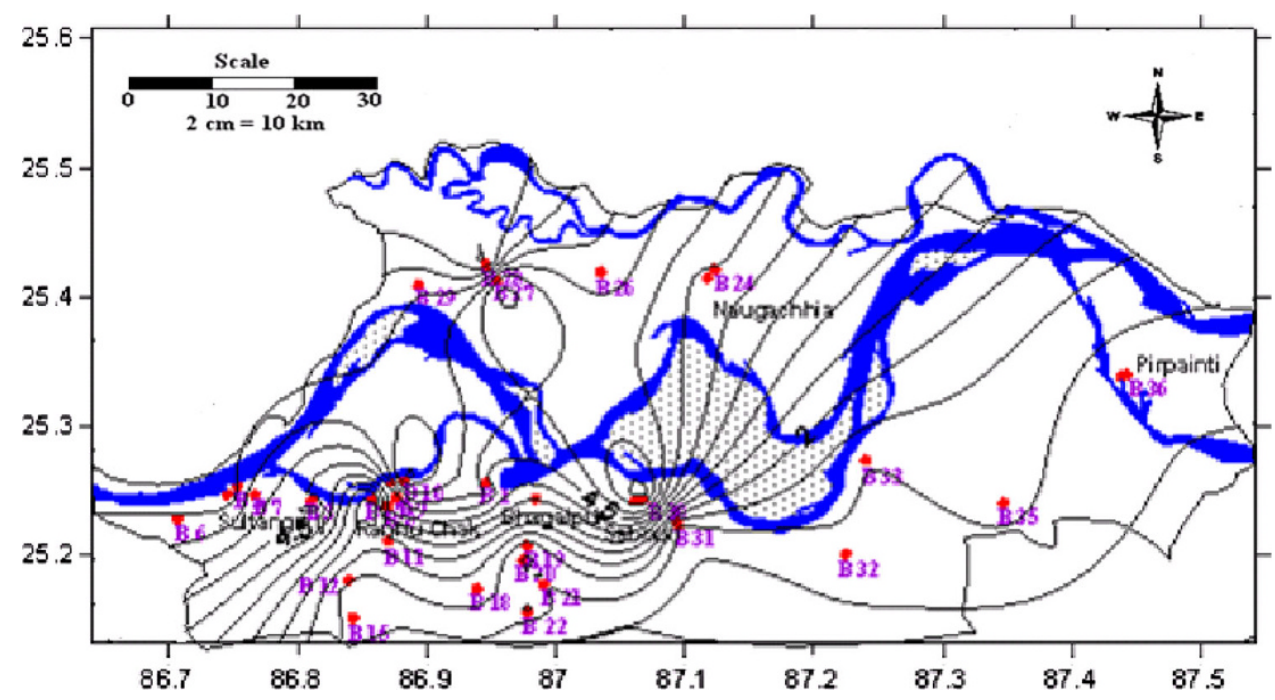

\begin{tabular}{lcrcrrr}
\hline Sample/SI & $\mathrm{PCO}_{2}$ & Calcite & Dolomite & $\mathrm{FeCO}_{3}$ & Geothite & $\mathrm{Fe}(\mathrm{OH})_{3}$ \\
\hline Golgamma & -1.447 & -0.332 & -1.611 & -2.557 & -0.172 & -0.053 \\
Panchrukhi & -1.898 & -0.182 & -0.735 & -1.608 & -0.436 & -1.708 \\
Marwa & -2.457 & 0.277 & -0.223 & -2.263 & 0.300 & -1.788 \\
Mahesitilakpur & -0.681 & 0.006 & -0.630 & -0.770 & 0.116 & -1.818 \\
Sultanganj & -0.614 & 2.415 & 1.240 & -0.599 & 0.619 & -2.048 \\
Bhagalpur & -1.858 & 1.648 & 0.458 & -0.382 & 0.530 & -1.917 \\
Sabour & -3.406 & 0.845 & 0.476 & -3.371 & 2.071 & -2.186 \\
Rannuchak & -2.146 & 1.441 & 2.462 & -1.316 & 1.430 & -1.598 \\
Pirpainti & -2.475 & 1.761 & 0.308 & -0.360 & -1.470 & -2.135 \\
Naugachhia & -1.708 & 1.542 & 0.521 & -0.925 & -1.869 & -2.137 \\
\hline
\end{tabular}

or as arsenide of iron, copper, nickel, cobalt ores, into the thick sedimentary deposit such as clay and their mobilization is being governed by the active terminal electron accepting processes (TEAPs) as reported by Bhattacharya et al. (2009).

Relationship between VES and hydrochemical signature of the aquifer

When the resistivity profile at point 3 was compared with the contour for both As and Fe, a good correlation was found which suggests that VES values can be used to delineate As-contaminated aquifer zone. The low resistivity which represents very fine silt and clay soil in subsurface which is believed to be deposited during meandering in a floodplain environment, has a strong anoxic condition to result in the negative Eh value along with high As and Fe concentrations in groundwater. Thus, such clay layer at shallow depth with abundant iron minerals along with high concentration of arsenic can be detected by geophysical as well as geochemical techniques.
Combined with the geochemical composition, this study reveals that the controlling factor of arsenic in ground water is redox condition and iron content of the aquifer and release of arsenic may depend on oxidation followed by reduction due to vertical movement of water. Finally, it can be concluded that "oxyhydroxide reduction theory" is responsible for release of arsenic in the aquifer of Bhagalpur.

\section{Conclusion}

This study reveals that resistivity survey is useful for predicting subsurface geological formation. It also gives information about soil salinity, water content, humus, texture especially presence of clay, silt and sand stone content. It is observed that at shallow depth, i.e., low resistivity zone $(>10 \Omega \mathrm{m})$, redox reactions support the release of As from arseniferous iron oxyhydroxides in the groundwater and the given facts were also validated through geochemical characterization of water samples (Kumar et al. 2010) and the borehole lithology (silty clay). 
For observation site, though the subsurface distribution pattern of clay layer is very irregular but in general after $40 \mathrm{~m}$ depth there is a thick layer of fine sand which can be labeled as potentially safe zone for groundwater extraction. This important finding can help the local driller/local administration in many ways to target arsenic-safe aquifer if resistivity survey will be done on extensive spatial scale.

Acknowledgments Authors would like to thank Indian Council of Medical Research (ICMR), Government of India for giving fellowship and grant for my research work. Without fail, we are also grateful to School of Environmental Sciences, Jawaharlal Nehru University, New Delhi, India for providing the Central Instrumentation Facility to complete all analytical works.

Open Access This article is distributed under the terms of the Creative Commons Attribution License which permits any use, distribution, and reproduction in any medium, provided the original author(s) and the source are credited.

\section{References}

Acharyya SK (2005) Arsenic levels in groundwater from Quaternary alluvium in the Ganga plain and the Bengal basin, Indian subcontinent: insight into influence of stratigraphy. Gond Res $8: 1-12$

Acharyya SK, Shah BA (2004) Risk of arsenic contamination in groundwater affecting Ganga alluvial plain India. Environ Health Perspect 112:A19-A20

Ahmed KM, Bhattacharya P, Hasan MA, Akhter SH, Alam MA, Bhuyian H, Imam MB, Khan AA, Sracek O (2004) Arsenic enrichment in groundwater of the alluvial aquifers in Bangladesh: an overview. Appl Geochem 19:181-200

American Public HealthAssociation (APHA) (1995) Standard methods for the examination of water and wastewater, 19th edn. American Public Health Association, Washington DC 1467

Aziz Z, van Geen A, Stute M, Versteeg R, Horneman A, Zheng Y, Goodbred S, Steckler M, Weinman B, Gavrieli I, Hoque MA, Shamsudduha M, Ahmed KM (2008) Impact of local recharge on arsenic concentrations in shallow aquifers inferred from the electromagnetic conductivity of soils in Araihazar, Bangladesh. Water Resour Res 44:W07416. doi:10.1029/2007WR006000

Banton O, Seguin MK, Cimon MA (1997) Mapping field-scale physical properties of soil with electrical resistivity. Soil Sci Soc Am J 61:1010-1017

Ben DS, Berner Z, Chandrasekharam D, Karmakar J (2003) Arsenic enrichment in groundwater of West Bengal, India: geochemical evidence for mobilization of As under reducing conditions. Appl Geochem 18:1417-1434

Bhattacharya P, Chatterjee D, Jacks G (1997) Occurrence of arsenic contamination of groundwater in alluvial aquifers from Delta plain, eastern India: option for safe drinking supply. Int J Water Res Dev 13:79-92

Bhattacharya P, Hasan MA, Sracek O, Smith E, Ahmed KM, von Brömssen M, Huq SMI, Naidu R (2009) Groundwater chemistry and arsenic mobilization in the Holocene flood plains in southcentral Bangladesh. Environ Geochem Health 31:23-44

Chakraborti D, Samanta MK, Rahman MM, Ahmed S, Chowdhury UK, Hossain MA, Mukherjee SC, Pati S, Saha KC, Dutta RN, Quamruzzaman Q (2004) Groundwater arsenic contamination and its health effects in the Ganga-Meghna-Brahmaputra plain. J Environ Monit 6:74N-83N

Charlet L, Chakraborty S, Appelo CAJ, Roman-Ross G, Nath B, Ansari AA, Lanson M, Chatterjee D, Mallik B (2007) Chemodynamics of an arsenic "hotspot" in a West Bengal aquifer: a field and reactive transport modeling study. Appl Geochem 22:1273-1292

Chauhan D, Nickson R, Iyengar L, Sankararamakrishnan N (2009) Groundwater geochemistry and mechanism of mobilization of arsenic into the ground water of Ballia district, Uttar Pradesh, India. Chemosphere 75(1):83-89

Gabel T (2000) Confounding variables in the environmental toxicology of arsenic. Toxicology 144:155-162

Harvey C, Swartz CH, Badruzzaman ABM, Keon-Blute NE, Yu W, Ashraf AM, Jay J, Beckie R, Niedam V, Brabander DJ, Oates PM, Ashfaque KN, Islam S, Hemond HF, Ahmed MF (2002) Arsenic mobility and groundwater extraction in Bangladesh. Science 298:1602-1606

Hoque MA, Khan AA, Shamsudduha M, Hossain MS, Islam T, Chowdhury SH (2009) Near surface lithology and spatial variation of arsenic in the shallow groundwater: southeastern Bangladesh. Environ Geol 56:1687-1695

Kumar P, Kumar M, Ramanathan AL, Tsujimura M (2010) Tracing the factors responsible for arsenic enrichment in groundwater of the middle Gangetic plain, India: a source identification perspective. Environ Geochem Health 32:129-146

Kumar P, Iwagami S, Yaping L, Mikita M, Tanaka T, Yamanaka T (2011) Multivariate approach for surface water quality mapping with special reference to nitrate enrichment in Sugadaira, Nagano prefecture (Japan). Environmentalist 31:358-363

Mazac O, Cislerova M, Kelly WE, Landa I, Venhodova D (1990) Determination of hydraulic conductivities by surface geoelectrical methods. In: S.H. Ward (ed) Geotechnical and environmental geophysics. V. 2 Environmental and groundwater applications, pp.125-131

Mukherjee S, Sashtri S, Gupta M, Pant MK, Singh C, Singh SK, Srivastava PK, Sharma KK (2007) Integrated water resource management using remote sensing and geophysical techniques: Aravali quartzite, Delhi, India. J Environ Hydro 15(10):1-10

Mukherjee A, von Brömssen M, Scanlon BR, Bhattacharya P, Fryar AE, Hasan MA, Ahmed KM, Chatterjee D, Jacks G, Sracek O (2008) Hydrogeochemical comparison and effects of overlapping redox zones on groundwater arsenic near the western (Bhagirathi sub-basin, India) and eastern margins (Meghna subbasin, Bangladesh) of the Bengal basin. J Contam Hydrol 99(1-4):31-48

Nath B, Mallik SB, Stuben D, Chatterjee D, Charlet L (2010) Electrical resistivity investigation of the arsenic affected alluvial aquifers in West Bengal, India: usefulness in identifying the areas of low and high groundwater arsenic. Environ Earth Sci 60:873-884

National Academy Press (2001) Arsenic in drinking water: 2001 update. Sub-committee to update the 1999 Arsenic in Drinking Water Report, Goyer R (Chair). National Academy Press, Washington, DC

Nickson RT, McArthur JM, Burgess WG, Ahmed KM, Ravenscroft P, Rahman M (1998) Arsenic poisoning of Bangladesh groundwater. Nature 395:338

Nickson RT, McArthur JM, Ravenscroft P, Burgess WG, Ahmed KM (2000) Mechanism of arsenic release to groundwater, Bangladesh and West Bengal. Appl Geochem 15:403-413

Paranis DS (1997) Principles of applied geophysics. Chapman \& Hall, UK

Raju NJ, Reddy TVK (1998) Fracture pattern and electric resistivity studies for groundwater exploration. Environ Geol 34:175-183 
Rhoades JD, Schilfgaarde JV (1976) An electrical conductivity probe for determining soil salinity. Soil Sci Soc Am J 40:647-650

Rhoades JD, Shouse PG, Alves WJ, Manteghi NA, Lesch SM (1990) Determining soil salinity from soil conductivity using different models and estimates. Soil Sci Soc Am J 54:46-54

Sankararamakrishnan N, Chauhan D, Nickson RT, Iyengar L (2008) Evaluation of two commercial field test kits used for screening of groundwater for arsenic in northern India. Sci Total Environ 401:162-167

Shah BA (2008) Role of Quaternary stratigraphy on arseniccontaminated groundwater from parts of Middle Ganga Plain, UP-Bihar, India. Environ Geol 35:1553-1561

Singh IB (2004) Late Quaternary history of the Ganga plain. J Geol Soc India 64:431-454

Smith AH, Lingas EO, Rahman M (2000) Contamination of drinking water by arsenic in Bangladesh: a public health emergency. Bull World Health Org 83:177-186
Srivastava AK, Govil PC, Tripathi RM, Shukla, Srivastava RS, Vaish DP, Nickson RT (2008) Groundwater for sustainable development: problems, perspectives and challenges. In: Bhattacharya P, Ramanathan AL, Mukherjee AB, Bundschuh J, Chandrasekharam D, Keshari AK (eds) Initial data on arsenic in groundwater and development of a state action plan, Uttar Pradesh, India. Taylor and Francis/A. A. Balkema, The Netherlands, pp 271281

WHO (World Health Organization) (2004) Guidelines for drinking water quality: training pack. WHO, Geneva

Wilding LP, Smeck NE, Hall GF (1983) Pedogenesis and soil taxonomy. I. Concepts and interactions. Developments in Soil Science, 11A. Elsevier, Amsterdan

Yadav GS, Singh SK (2007) Integrated resistivity surveys for delineation of fractures for ground water exploration in hard rock areas. J Appl Geophy 62(3):301-312 